Clements, F. A., Arab Regional Organizations [Bibliography]. Oxford and New Brunswick (NJ), 1992

Gomaa, A. M., The Foundation of the League of Arab States. London, 1977

\title{
ARAB FUND FOR ECONOMIC AND SOCIAL DEVELOPMENT (AFESD)
}

Established in 1968, the Fund commenced operations in 1974.

Aims. To contribute to the financing of economic and social development in Arabic states through: financing economic and social development projects by making loans on concessionary terms to governments and public enterprises and corporations, giving preference to projects which are vital to the Arab world and to inter-Arab projects; and financing private sector projects in member states by providing all forms and loans and guarantees to corporations and enterprises processing juridical personality.

Members. Algeria, Bahrain, Djibouti, Egypt, Iraq*, Jordan, Kuwait, Lebanon, Libya, Mauritania, Morocco, Oman, Palestine, Qatar, Saudi Arabia, Somalia*, Sudan, Syria, Tunisia, United Arab Emirates, Republic of Yemen. *Membership suspended since 1993.

Headquarters: PO Box 21923, Safat 13080, Kuwait.

Website: http://www.arabfund.org

Director General and Chairman of the Board of Directors: Abdulatif Y. A1 Hamad.

Publications. Annual Report; Joint Arab Economic Report.

\section{ARAB MONETARY FUND (AMF)}

Origin. The Agreement establishing the Arab Monetary Fund was approved by the Economic Council of the League of Arab States in April 1976 and the first meeting of the Board of Governors was held on 19 April 1977.

Aims. To assist member countries in eliminating payments and trade restrictions, in achieving exchange rate stability, in developing capital markets and in correcting payments imbalances through the extension of short- and medium-term loans; the co-ordination of monetary policies of member countries; and the liberalization and promotion of trade and payments, as well as the encouragement of capital flows among member countries.

Members. Algeria, Bahrain, Comoros, Djibouti, Egypt, Iraq, Jordan, Kuwait, Lebanon, Libya, Mauritania, Morocco, Oman, Palestine, Qatar, Saudi Arabia, Somalia, Sudan, Syria, Tunisia, United Arab Emirates, Republic of Yemen.

Headquarters: PO Box 2818, Abu Dhabi, United Arab Emirates.

Website: http://www.amf.org.ae

Director General and Chairman of the Board of Directors: Jassim A. Al-Mannai.

Publications (in English and Arabic): Annual Report; The Articles of Agreement of the Arab Monetary Fund; Money and Credit in Arab Countries (annual); National Accounts of Arab Countries (annual); Foreign Trade of Arab Countries (annual); Cross Exchange Rates of Arab Currencies (annual); Arab Countries: Economic Indicators (annual); Balance of Payments and External Public Debt of Arab Countries (annual); AMF Publications Catalogue (annual); Arab Monetary Fund: Structure and Activities (1977-83). (In Arabic only): The Joint Arabic Economic Report (annual); AMF Economic Bulletin; Developments in Arab Capital Markets (quarterly). 